\title{
The insurance market in the young population of Ciudad Nezahualcóyotl
}

\section{El mercado de seguros en la población joven de Ciudad Nezahualcóyotl}

\author{
ÁLVAREZ-GARCÍA, Mónica, GUERRERO-IBARRA, Carlos, GUTIÉRREZ-JIMÉNEZ, Silvia and \\ LARIOS-CALVA, Margarita
}

Universidad Tecnológica de Nezahualcóyotl

ID $1^{\text {st }}$ Author: Mónica, Álvarez-García / ORC ID: 0000-0003-3393-1277, Researcher ID Thomson: B-8810-2019

ID $1^{\text {st }}$ Coauthor: Carlos, Guerrero-Ibarra / ORC ID: 0000-0003-0958-7912

ID $2^{\text {nd }}$ Coauthor: Carlos, Guerrero-Ibarra / Researcher ID Thomson: B-4409-2018

ID $3^{\text {rd }}$ Coauthor: Margarita, Larios-Calva / ORC ID: 0000-0002-2356-7419, CVU CONACYT ID: 1000061

DOI: $10.35429 / J B A B .2019 .4 .3 .9 .14$

Received March 22, 2019; Accepted June 15, 2019

Abstract

The insurance market in Mexico has grown slowly even though crime has increased in recent years, this is due to the lack of risk prevention culture within the population. Regarding young people, nowadays with the advance of new technologies, the use of cell phones, tablets, laptops and video games has increased. Likewise, for them, the favorite means of transport are "motorcycles and bicycles," which is why some insurance companies are working to offer new and diverse products, thus seeking a change in the use of insurance by the future customers: the "Millennials." Insecurity is one of the great problems that afflict our country. It has gone from car and house theft, to the theft of the vehicles most used by young people: motorcycles. According to figures from the Mexican Association of Insurance Institutions (AMIS), motorcycles of the Italika and Honda brands were among the 10 most stolen insured vehicles in the period from May 2017 to April 2018 (eldictamen.mx). Regarding cell phones, Anatel (National Communications Association) General Director Gabriel Székely said that in 2016, 900 thousand were stolen, while 2017 exceeded one million (heraldodemexico.com.mx). The general objective of this project is to find out if Millennials currently have a culture of insuring their belongings against theft and if this new market sector of young people can be considered. A documentary review and descriptivequantitative research was carried out in Bosques de Aragón, Nezahualcóyotl, with a sample of 122 young people between 15 and 29 years of age. In the documentary review it was detected that car and life policy insurances are the most sold by insurance companies. According to the National Insurance and Bail Bonding Commission (CNSF), in this regard, the insurance companies have the possibility of creating new and better services that can cover the equipment currently being used by young people and, at the same time, increase their market. The results obtained show that $89 \%$ of the population investigated considers that it is important to have insurance and $36 \%$ have one, mainly for cars or life, but they never mentioned having electronic equipment or motorcycles insured.

Millenials, Market, Insurance

\begin{abstract}
Resumen
El mercado de seguros en México ha crecido lentamente a pesar de que el crimen ha aumentado en los últimos años, esto se debe a la falta de cultura de prevención de riesgos dentro de la población. Con respecto a los jóvenes, hoy en día con el avance de las nuevas tecnologías, el uso de teléfonos celulares, tabletas, computadoras portátiles y videojuegos ha aumentado. Del mismo modo, para ellos, el medio de transporte favorito son las "motocicletas y bicicletas", por lo que algunas compañías de seguros están trabajando para ofrecer productos nuevos y diversos, buscando así un cambio en el uso del seguro por parte de los futuros clientes: los "Millennials". " La inseguridad es uno de los grandes problemas que aquejan a nuestro país. Se ha pasado del robo de automóviles y casas al robo de los vehículos más utilizados por los jóvenes: las motocicletas. Según las cifras de la Asociación Mexicana de Instituciones de Seguros (AMIS), las motocicletas de las marcas Italika y Honda estuvieron entre los 10 vehículos asegurados más robados en el período de mayo de 2017 a abril de 2018 (eldictamen.mx). Con respecto a los teléfonos celulares, el director general de Anatel (Asociación Nacional de Comunicaciones), Gabriel Székely, dijo que en 2016, 900 mil fueron robados, mientras que 2017 superó el millón (heraldodemexico.com.mx). El objetivo general de este proyecto es averiguar si los Millennials actualmente tienen una cultura de asegurar sus pertenencias contra el robo y si se puede considerar este nuevo sector de mercado para los jóvenes. Se realizó una revisión documental e investigación descriptiva-cuantitativa en Bosques de Aragón, Nezahualcóyotl, con una muestra de 122 jóvenes entre 15 y 29 años. En la revisión documental se detectó que los seguros de automóviles y pólizas de vida son los más vendidos por las compañías de seguros. Según la Comisión Nacional de Seguros y Fianzas (CNSF), a este respecto, las compañías de seguros tienen la posibilidad de crear nuevos y mejores servicios que puedan cubrir el equipo que utilizan actualmente los jóvenes y, al mismo tiempo, aumentar su mercado . Los resultados obtenidos muestran que el $89 \%$ de la población investigada considera que es importante contar con un seguro y el $36 \%$ tiene uno, principalmente para automóviles o de vida, pero nunca mencionaron tener asegurados los equipos electrónicos o las motocicletas.
\end{abstract}

Citation: ÁLVAREZ-GARCÍA, Mónica, GUERRERO-IBARRA, Carlos, GUTIÉRREZ-JIMÉNEZ, Silvia and LARIOSCALVA, Margarita. The insurance market in the young population of Ciudad Nezahualcóyotl. Journal- Business Administration -Marketing; Accounting. 2019. 3-4: 9-14

$\dagger$ Researcher contributing as first author. 


\section{Problem statement}

Liébano Sáenz (2018) considers, in the survey "The most inhabited cities" carried out in the municipalities of Chimalhuacán, Ecatepec and Nezahualcóyotl, that these are the most inhabited and dangerous in the State of Mexico.

Insecurity in Mexico has reached very high levels. According to the National Survey of Urban Public Security carried out by INEGI (2019), $73 \%$ of the population age 18 and over consider that living in their city is unsafe. Given the high rates of insecurity, many offers have emerged from insurance companies to protect citizens' belongings against theft.

In the Municipality of Nezahualcóyotl today, more and more young people own a motorcycle, bicycle, laptop or cell phone. It has become very common or "fashionable" to use these objects in order to facilitate communication and transportation.

The task of Insurance Companies is to make young people aware of the importance of buying insurances to keep their belongings safe, as well as the means for the recovery of the monetary investment that they make when acquiring their diverse goods.

However, it is not so common in the municipality for a young person to purchase an insurance policy against theft; they prefer to buy clothes, convenience products or invest in recreational or leisure activities.

Hence, the question arises:

Is there a culture and acquisition of an insurance policy to protect their belongings against theft in the youth market segment in Nezahualcóyot City?

\section{General objective}

To know if there is a culture of insurance of belongings against theft in the Millenials market, as a prevention measure, given the situation of insecurity that prevails in Mexico.

\section{Specific objectives:}

1. To identify young people's knowledge of insurance companies.
2. To detect if they know the different insurance policies offered by the insurance companies.

3. To detect if young people know the types of insurance against theft that exist on the market.

4. To know the importance that young people give to the acquisition of a theft insurance policy.

5. To identify if they have acquired a theft insurance policy.

6. To know what type of theft insurance policy they have purchased.

7. To identify the type of insurance policy they would be willing to pay for according to their needs and belongings.

8. To identify how much they would be willing to pay monthly for a theft insurance policy.

\section{Methodology}

Young people between 20 and 29 years of age resident in the Bosques de Aragón neighborhood in the municipality of Nezahualcóyotl, with a C+ level (because the population has an income or standard of living slightly higher than the average level), were taken as the study universe. According to the Census of Population and Housing, INEGI 2010; Nezahualcóyotl has a total of 1,110,565 inhabitants and according to Marketdatamexico, around 27,000 people live in 8,000 houses that represent $24 \%$ of the total population of the Municipality. 185,797 inhabitants are from 20 to 29 years of age, resulting in 4,459 young people under study.

The sample was determined using the formula of the normal distribution curve for finite populations and we worked with the $95 \%$ confidence interval and a standard error $+-8.5 \%$ with a probability for and against $50 \%$, resulting in 122 elements to be selected from the study universe.

The research was supported by the student Mendoza Jiménez Brenda Olivia, who conducted the market research for GRUPO OLMAR, S.A. where she worked with the study universe of young people, which INEGI in its book "Los Jóvenes en México" classifies them in the age range of 15 to 29 years; however, we took into consideration people from 20 years on, who are young people who can make decisions and have some income. 
To collect the information, a structured 9-question questionnaire was used, which was applied through personal interviews directly in the neighborhood, using a convenience sampling, where the elements were selected according to their availability to participate in the research, later the questionnaires were coded and processed in the SPSS program.

\section{Documentation research}

In its book "Los Jóvenes en México", INEGI describes that in $1997,34.9 \%$ of the inhabitants of the country were between the ages of 0 and 14 , while $28.8 \%$ were young people between the ages of 15 and 29. In the year 2000, the population of children decreased, but the percentage of young people has remained at $29.4 \%$ at the national level, thus defining the population between 15 and 29 years old as young.

According to the 2010 population census, the total population of Nezahualcóyotl was $1,110,565$, and the population between the ages of 15 and 29 was 284,411 , or $26 \%$ of the population.

Regarding the insurance market, Saldivar in the newspaper El Economista mentioned that in Mexico, the slow development that the insurance market has had is a great opportunity for insurers to offer new products and meet the needs of customers, said Javier Rodriguez de Zurich Mexico (Saldivar B., 2018). Studies (Recaredo, J., 2017) in 2016 and 2017 by the Mexican Association of Insurance Institutions (AMIS) mentioned that car and life policies are the most sold.

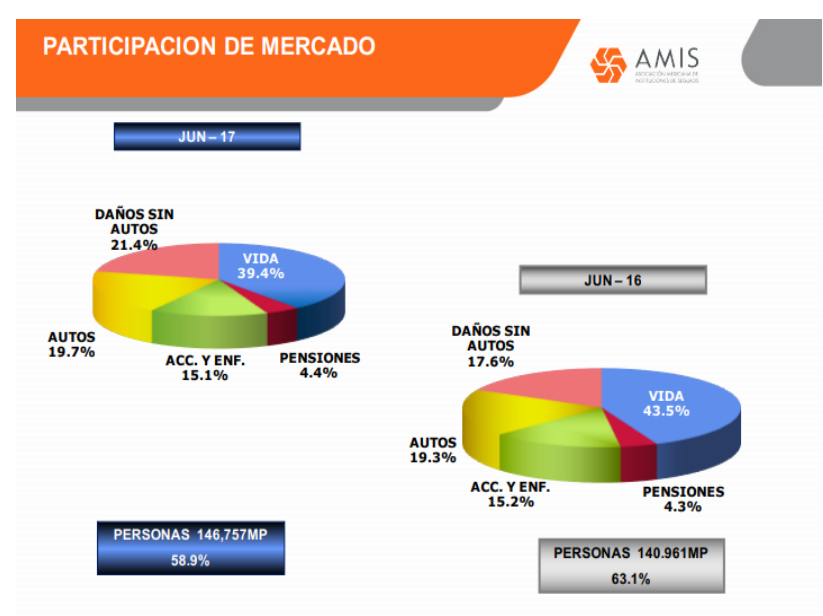

Graphic 1 Empresas Aseguradoras/Bienes asegurados AMIS
The AMIS Director notes that in 2018, the ten most stolen vehicle brands are NISSAN, for cars and vans, and ITALIKA, for motorcycles (Forbes, 2019).

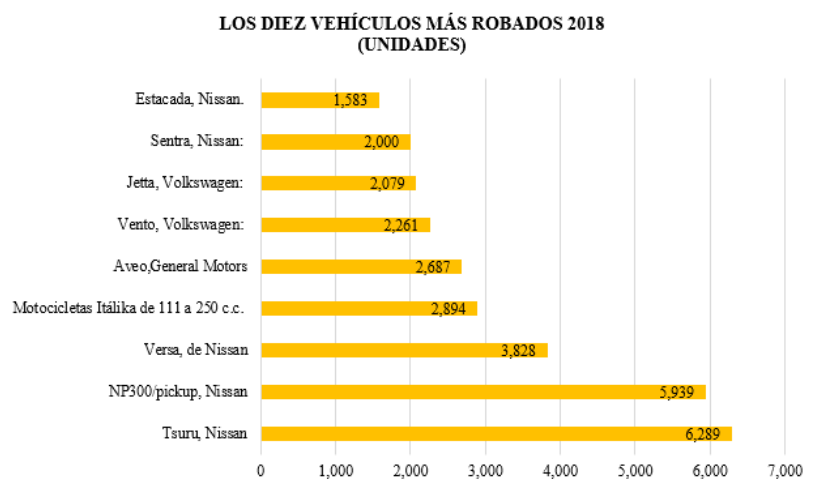

Graphic 2 Own Elaboration / Information extracted from Forbes 2019

Unfortunately, in Mexico the most stolen equipment, apart from cars, are cell phones and motorcycles. The theft of these showed a rise in the last 12 months, ending last April. Particularly, Italika motorcycles had the highest growth in this crime, with $162.5 \%$ over the same period last year.

According to figures from the Mexican Association of Insurance Institutions (AMIS), Italika and Honda motorcycles were among the 10 most stolen insured vehicles in the period from May 2017 to April 2018.

These two brands presented a total of 4,185 units stolen in the reference period, an increase of $88.9 \%$ over the same period last year, when 2,215 motorcycles were stolen (Valera, C., 2018).

The National Telecommunications Association (ANATEL) reports via the newspaper La Jornada that the number of mobile device theft in Mexico has increased dramatically in recent years: in 2012 there were 156,000 reported thefts, in 2015 the report was 600,000 units, and a year later the report closed at 900,000 . And by 2017, the organization expects to exceed one million stolen smartphones, a figure that represents a growth of over 500\% (Cahun, A. (2017).

However, young people spend the most on clothing, travel and electronics. The electronic equipment that they own the most are: Smart Phones, Tablets, Videogames, Lap tops and Personal Computers (P.C.). 


\section{Research findings}

As can be seen in Figure 1 and 2, almost 9 out of 10 within the youth market considers important to have an insurance.

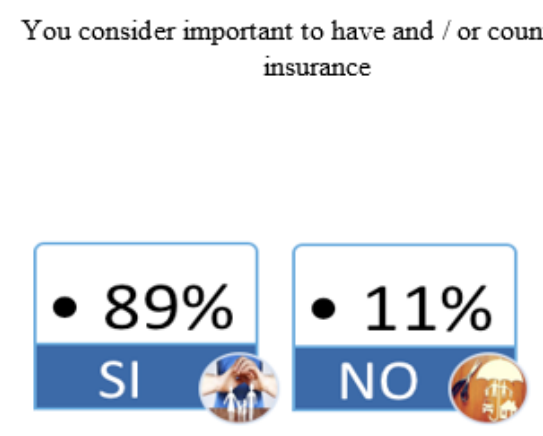

Base interviews 122

Figure 1 Own elaboration, data obtained from Market Research for GRUPO OLVAR

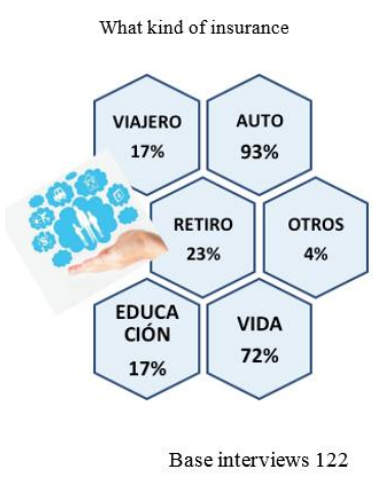

Figure 2 Own elaboration, data obtained from Market Research for GRUPO OLVAR

In the investigation, they were asked which companies they know or have heard of, this allowed them to detect the positioning of companies, as can be seen in Graph 1, some of those interviewed mentioned two or three names, the highest was Qualitas, 8 out of 10 young people said they knew it, while $71 \%$ mentioned GNP, 65\% Metlife, and other companies have percentages lower than $57 \%$.

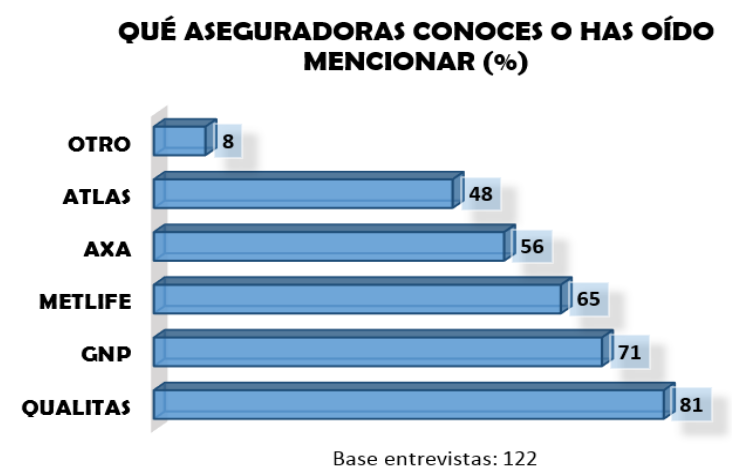

Graph 3 Own elaboration, data obtained from Market research for Grupo Olvar

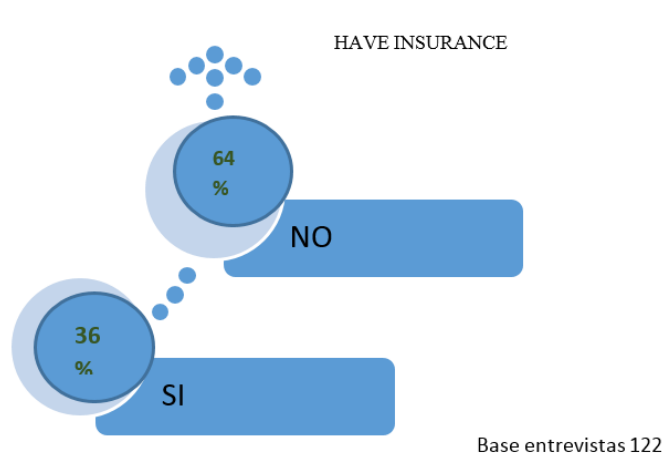

Figure 3 Own elaboration, data obtained from Market Research for GRUPO OLVAR.

This question helped to detect if there is a culture of belongings insurance, in figure 3 there is not a culture, because only a third of the interviewees said to have insurance, the policy they said to have is for life and cars. One of the objectives of this project was to learn about the culture that young people have in acquiring insurance to protect their belongings.

The previous question inquired about the possession of some policy, the investigation showed that very few people have it; to investigate if there is any intention of acquiring one, we evaluated the willingness to purchase it to protect themselves, however as can be seen in the figure, less than half agreed to purchase it and those who agreed were only interested in life insurance $(30 \%)$ and car insurance $(17 \%)$.

You would be willing to acquire an insurance

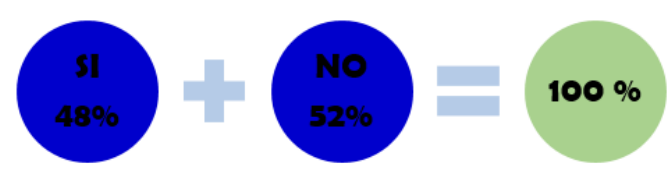

Figure 4 Own elaboration, data obtained from Market Research for GRUPO OLVAR

\section{TIPO DE SEGURO DEL OUE OUIERE RECIBIR INFORMACIÓN (\%)}

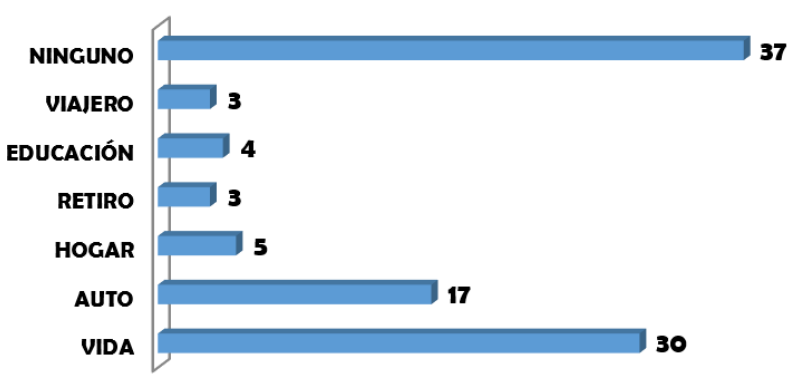

Graph 4 Own elaboration, data obtained from Market research for Grupo Olvar 
Finally, the interviewees were asked how much they would be willing to invest in insurance and if they would like to receive information on any insurance. The information obtained was that more than half would pay the minimum amount of $\$ 500.00$ to $\$ 1,500.00$, only $48 \%$ are interested in receiving such information in person and telephone, to clarify all their doubts and thus have a more direct contact with the Insurance Advisor.

¿CUÁNTO ESTARÍA DISPUESTO A PAGAR POR UN SEGURO?

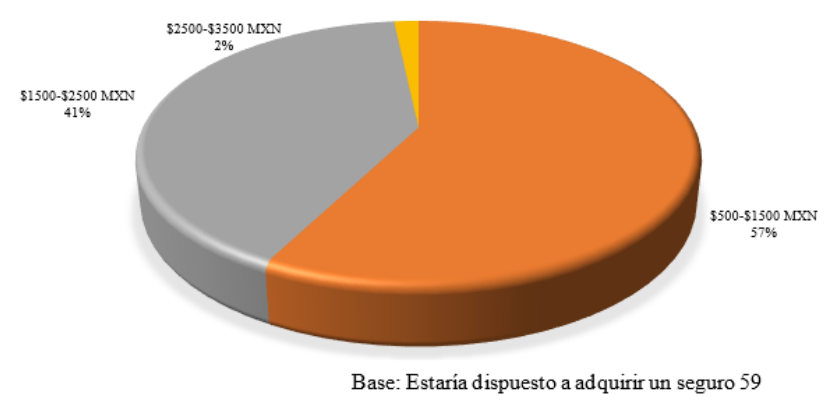

Graph 5 Own elaboration, data obtained from Market research for Grupo Olvar

\section{MEDIO POR EL QUE TE GUSTARÍA RECIBIR INFORMACIÓN (\%)}

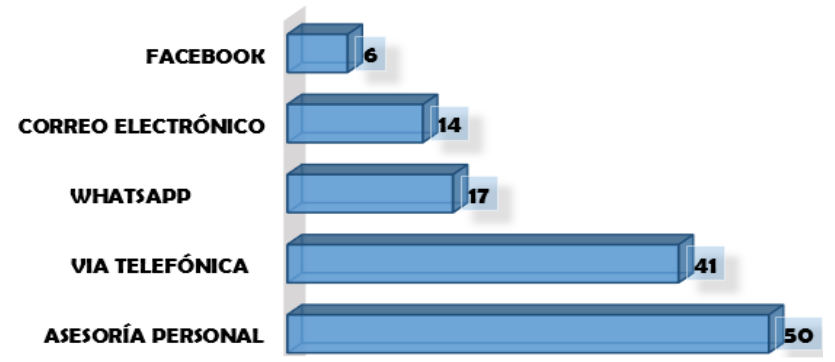

Graph 6 Own elaboration, data obtained from Market research for Grupo Olvar

\section{Conclusions}

After conducting the research, it was concluded that the youth of Nezahualcóyotl City have no insurance culture, as only a third said they had one. Life and car insurances are the most sold, although currently they use more cell phones, tablets, lap tops and, as a means of transportation, "motorcycles." It should be noted that in order to travel on federal roads "The Law of Roads, Bridges and Federal Transportation" stipulates that all owners of vehicles (including motorcycles) must have mandatory liability insurance. For the same reason, there are currently several insurance companies that offer insurance policies for motorcycles, this sector is not fully covered.
Thus, we determine that it is a market segment that can be important for insurance companies, because young people do not have insurance policies that fully cover these products yet. Marketing strategies must be implemented to convince them and, in addition to this, "Awareness campaigns" related to the importance of acquiring a policy, due to the insecurity that prevails in the country, since only 4 out of 10 young people would be willing to purchase an insurance.

\section{References}

Cahun A. (2017), article taken from: https://www.xataka.com.mx/celulares-ysmartphones/robo-de-celulares-en-mexicoincremento-de-500-en-seis-anos-en-2017-sesuperara-un-millon-de-unidades

El cronista, 2016, article taken from:https://www.cronista.com/negocios/Losjovenes-menores-de-25-anos-son-los-que-mascompran-smartphones-20160728-0034.html Copyright (C) www.com

Forbes, 2019, Estos-son-los-10-autos-masrobados-en-2018, article taken from: https://www.forbes.com.mx/estos-son-los-10autos-mas-robados-en-2018/

Hoy Estado.com. https://www.hoyestado.com/2018/08/calificana-neza-chimalhuacan-y-ecatepec-como-lospeores-lugares-para-vivir/. $08 \quad 22,2018$. https://www.hoyestado.com/2018/08/calificana-neza-chimalhuacan-y-ecatepec-como-lospeores-lugares-para-vivir/ (accessed 08 12, 2019).

https://www.marketdatamexico.com/es/article/ Colonia-Bosques-De-Aragon-NezahualcoyotlEstado-Mexico, Colonia Bosques De Aragón, Nezahualcóyotl, en Estado de México

INEGI. Encuesta Nacional de Seguridad Pública Urbana. Edited by INEGI. June 10, 2019. https://www.inegi.org.mx/contenidos/saladepre nsa/boletines/2019/ensu/ensu2019_07.pdf (accessed Agosto 12, 2019).

Los Jóvenes en México, 2000, INEGI 
Panorama Sociodemográfico de Estado de México 2015, INEGI taken from $\mathrm{http} / / /$ internet.contenidos.inegi.org.mx/contenid os/Productos/prod_serv/contenidos/espanol/bvi negi/productos/nueva_estruc/inter_censal/panor ama/702825082246.pdf 